Original Contribution

\title{
ASSESMENT OF THE RESISTANCE OF CLINICAL ISOLATES PSEUDOMONAS AERUGINOSA TO QUINOLONONES
}

\author{
E. Savov ${ }^{1 *}$, A. Trifonova ${ }^{1}$, I. Todorova ${ }^{1}$, I. Gergova ${ }^{1}$, M. Borisova ${ }^{1}$, M. Ananieva ${ }^{2}$, \\ E. Kjoseva ${ }^{1}$, V. Kardjeva ${ }^{2}$ \\ ${ }^{1}$ Laboratory of Microbiology, Military Medical Academy (MMA), Sofia, Bulgaria \\ ${ }^{2}$ AQUACHIM Company, Bulgaria
}

\begin{abstract}
Thirty multidrug-resistant P.aeruginosa strains, isolated from clinical samples during 2011-2012, were investigated for the mechanisms' of resistance determination to quinolones. It is the first report in Bulgaria regarding the detection of point mutations in the quinolone resistance-determining regions of gyrA and parC as well as for the efflux pomp regulatory mexR genes by the Sanger sequencing method. Mutations, related to quinolone resistance were detected in codon 83 of gyr A gene, codons 87 and 136 of the parC and codons 126 and 44 of the mexR regulatory gene. Mutations in gyr A gene were found in all P.aeruginosa strains, resistant to ciprofloxacin.
\end{abstract}

Key words: Multidrug-resistance, Pseudomonas aeruginosa, point mutations, Sanger sequencing

\section{INTRODUCTION}

Pseudomonas aeruginosa is a non-fermenting Gram-negative microorganism which is a major dreaded cause of infection among hospitalized patients, usually with localized or systemic impairment of immune defence. It is a common cause of hospital-acquired infections like pneumonia, urinary-tract infections, wound infections, respiratory tract infections, bloodstream infections, especially in the units with high risk for infection development $(1,2)$. According to our data for $2011, \mathrm{P}$. aeruginosa occupies the 5th place with $7.2 \%$ among the first 10 most frequently isolated microorganisms in MMA and with $17.1 \%$ isolation in ICU, as well (3). Resistance to currently available antibiotics in nosocomial Gram-negative isolate, especially in multidrug-resistant $P$. aeruginosa strains has become a significant problem over the past decade (4). Due to the significant intrinsically expressed resistance of the $\mathrm{P}$. aeruginosa strains to the majority of antimicrobial compounds, the antibiotic classes that remain active include

*Correspondence to: Encho Savov, Military Medical Academy, Sofia, Bulgaria, tel: 0035929522773,

E-mail: savove@yahoo.com fluoroquinolones, aminoglycosides, carbapenems and colistin (1). But the problem, which is very important for the treatment of infections, caused by these microorganisms, is the resistance development to quinolones in the last years. The main mechanisms of resistance are mutations in the target genes, those encoding DNA gyrase $($ gyrA) and topoisomerase IV $(\operatorname{parC})(2,5,6)$ and in regulatory genes for drug efflux pumps (7).

The aim of this study is to examine the occurrence of mutations related to fluoroquinolones resistance ( $g y r A$ and $\operatorname{parC}$ genes) and regulatory genes for drug efflux pumps - mexR, using the Sanger sequencing technique of 30 clinical strains of $\mathrm{P}$. aeruginosa, isolated at Military Medical Academy in Sofia, Bulgaria.

\section{MATERIALS AND METHODS Clinical isolates}

Thirty multidrug-resistant $\mathrm{P}$. aeruginosa strains, isolated during 2011-2012 with a resistant profile to fluoroquinolones, were investigated. The isolates have been recovered from different clinical samples in patients who were treated in Intensive care units (ICU), Anesthesiology and 
SAVOVE., et al.

Resuscitation clinic (ARC), Hepato-pancreatic surgery (HPS), Traumatology, and in ambulatory patients at the Military Medical Academy, Sofia (Table 1). The identification and antimicrobial susceptibility profiling analysis of the isolates were performed by Vitek 2 (bioMérieux, France) and conventional methods (8) and the resistance' results were interpreted according to the CLSI guideline (9)

Table 1. Characteristic of the strains $P$. aeruginosa investigated

\begin{tabular}{|c|c|c|c|c|c|c|c|c|c|c|c|c|c|}
\hline № & Lab № & Clinic & Specimen & tzp & caz & fep & scf & mem & amk & gen & tbm & cip & Ivf \\
\hline 1 & $9459-10$ & Traum & wound & - & $\mathrm{S}$ & - & $\mathrm{S}$ & $\mathrm{S}$ & $\mathrm{S}$ & $\mathrm{S}$ & - & $\mathrm{S}$ & $\mathrm{S}$ \\
\hline 2 & $6489-11$ & $\mathrm{Amb}$ & pus & $S$ & $S$ & $\mathrm{~S}$ & $\bar{S}$ & $\mathrm{~S}$ & $\mathrm{~S}$ & $\mathrm{~S}$ & $\mathrm{~S}$ & $\mathrm{R}$ & - \\
\hline 3 & 9355-11 & HPS & urine & $\mathrm{R}$ & $\mathrm{R}$ & $\mathrm{R}$ & - & $\mathrm{S}$ & $\mathrm{S}$ & $\mathrm{S}$ & $\mathrm{S}$ & $\mathrm{S}$ & - \\
\hline 4 & $9802-11$ & $\overline{\mathrm{ARC}}$ & ur.cath. & $\overline{\mathrm{R}}$ & $\mathrm{R}$ & $\overline{\mathrm{R}}$ & - & $\bar{R}$ & $\overline{\mathrm{R}}$ & $\overline{\mathrm{R}}$ & $\overline{\mathrm{R}}$ & $\overline{\mathrm{R}}$ & $\bar{R}$ \\
\hline 5 & $10019-11$ & $\mathrm{ICU}$ & blood & $\mathrm{S}$ & $\mathrm{S}$ & $\mathrm{S}$ & - & $\mathrm{S}$ & $\mathrm{S}$ & $\mathrm{S}$ & - & $\mathrm{S}$ & $\mathrm{S}$ \\
\hline 6 & $10387-11$ & ICU & urine & $\mathrm{S}$ & $\mathrm{S}$ & $\mathrm{S}$ & - & $\mathrm{S}$ & $\mathrm{S}$ & $\mathrm{S}$ & $\mathrm{S}$ & $\mathrm{S}$ & - \\
\hline 7 & $10417-11$ & ARC & resp. s-m & $\mathrm{R}$ & $\mathrm{R}$ & $\mathrm{R}$ & - & $\mathrm{R}$ & $\mathrm{R}$ & $\mathrm{R}$ & $\mathrm{S}$ & $\mathrm{R}$ & - \\
\hline 8 & $10653-11$ & ARC & resp. s-m & $\bar{S}$ & $\bar{R}$ & $\mathrm{~S}$ & - & $\mathrm{R}$ & $\bar{I}$ & $\bar{R}$ & - & $\bar{R}$ & $\mathrm{R}$ \\
\hline 9 & 10944-11 & $\mathrm{ICU}$ & urine & $\mathrm{S}$ & $\mathrm{R}$ & $\mathrm{R}$ & - & $\mathrm{R}$ & $\mathrm{R}$ & $\mathrm{R}$ & - & $\mathrm{R}$ & $\bar{R}$ \\
\hline 10 & $10950-11$ & ICU & urine & $S$ & $\mathrm{R}$ & $\mathrm{R}$ & - & $\mathrm{R}$ & $\mathrm{R}$ & $\mathrm{R}$ & - & $\mathrm{R}$ & $\mathrm{R}$ \\
\hline 11 & $10983-11$ & ARC & urine & $\bar{R}$ & $\bar{R}$ & $\mathrm{R}$ & - & $\overline{\mathrm{R}}$ & $\mathrm{R}$ & $\mathrm{R}$ & - & $\mathrm{R}$ & $\overline{\mathrm{R}}$ \\
\hline 12 & $10993-11$ & $\overline{\mathrm{ARC}}$ & resp. s-m & $S$ & $\mathrm{R}$ & $\mathrm{S}$ & - & $\mathrm{R}$ & $\mathrm{S}$ & $S$ & - & $\mathrm{R}$ & I \\
\hline 13 & $11000-11$ & ARC & urine & $\mathrm{R}$ & $\mathrm{R}$ & $\mathrm{R}$ & - & $\mathrm{R}$ & $\mathrm{R}$ & $\mathrm{R}$ & - & $\mathrm{R}$ & $\mathrm{R}$ \\
\hline 14 & 11974-11 & ARC & wound & $\mathrm{R}$ & $\mathrm{R}$ & $\mathrm{R}$ & - & $\mathrm{R}$ & $\mathrm{R}$ & $\mathrm{R}$ & $\mathrm{R}$ & $\mathrm{R}$ & - \\
\hline 15 & $12023-11$ & ICU & blood & $\mathrm{R}$ & $\mathrm{R}$ & $\mathrm{R}$ & - & $\overline{\mathrm{R}}$ & $\mathrm{R}$ & $\mathrm{R}$ & $\mathrm{R}$ & $\mathrm{R}$ & - \\
\hline 16 & $12071-11$ & ARC & urine & $\mathrm{R}$ & $\mathrm{R}$ & $\mathrm{R}$ & - & $\mathrm{R}$ & $\mathrm{R}$ & $\mathrm{R}$ & $\mathrm{R}$ & $\mathrm{R}$ & - \\
\hline 17 & $12215-11$ & ARC & urine & $\mathrm{R}$ & $\mathrm{R}$ & $\mathrm{R}$ & - & $\mathrm{R}$ & $\mathrm{R}$ & $\mathrm{R}$ & - & $\mathrm{R}$ & $\mathrm{R}$ \\
\hline 18 & $12245-11$ & ARC & urine & I & $\mathrm{R}$ & $\mathrm{R}$ & - & $\mathrm{R}$ & $\mathrm{R}$ & $\mathrm{R}$ & - & $\mathrm{R}$ & $\mathrm{R}$ \\
\hline 19 & $12275-11$ & ARC & urine & $\mathrm{R}$ & $\mathrm{R}$ & $\mathrm{R}$ & - & $\mathrm{R}$ & $\mathrm{R}$ & $\mathrm{R}$ & - & $\mathrm{R}$ & $\mathrm{R}$ \\
\hline 20 & $12332-11$ & ARC & wound & $\mathrm{R}$ & $\mathrm{R}$ & $\mathrm{R}$ & - & $\mathrm{R}$ & $\mathrm{R}$ & $\mathrm{R}$ & - & $\mathrm{R}$ & $\mathrm{R}$ \\
\hline 21 & $12380-11$ & ICU & resp. s-m & $\mathrm{R}$ & $\mathrm{R}$ & $\mathrm{R}$ & - & R & $\mathrm{R}$ & $\bar{R}$ & $\mathrm{R}$ & $\mathrm{R}$ & - \\
\hline 22 & $12415-11$ & ICU & blood & $\mathrm{R}$ & $\mathrm{R}$ & $\mathrm{R}$ & - & $\mathrm{R}$ & $\mathrm{R}$ & $\mathrm{R}$ & $\mathrm{R}$ & $\mathrm{R}$ & - \\
\hline 23 & $12451-11$ & ARC & urine & $\mathrm{R}$ & $\mathrm{R}$ & $\mathrm{R}$ & - & $\mathrm{R}$ & $\mathrm{R}$ & $\mathrm{R}$ & $\mathrm{R}$ & $\mathrm{R}$ & - \\
\hline 24 & $204-12$ & ARC & urine & $\mathrm{R}$ & $\mathrm{R}$ & $\mathrm{R}$ & - & $\mathrm{R}$ & $\mathrm{R}$ & $\mathrm{R}$ & $\mathrm{R}$ & $\mathrm{R}$ & - \\
\hline 25 & $411-12$ & $\mathrm{ICU}$ & resp. s-m & $\mathrm{R}$ & $\mathrm{R}$ & $\mathrm{R}$ & - & $\mathrm{R}$ & $\mathrm{R}$ & $\mathrm{R}$ & $\mathrm{R}$ & $\mathrm{R}$ & - \\
\hline 26 & $465-12$ & ARC & urine & $\mathrm{R}$ & $\mathrm{R}$ & $\mathrm{R}$ & - & $\mathrm{R}$ & $\mathrm{R}$ & $\mathrm{R}$ & $\mathrm{R}$ & $\mathrm{R}$ & - \\
\hline 27 & $507-12$ & $\mathrm{Amb}$ & urine & $S$ & $\mathrm{~S}$ & $\mathrm{~S}$ & - & $\bar{S}$ & $\mathrm{~S}$ & $\mathrm{~S}$ & $\mathrm{~S}$ & $\mathrm{~S}$ & - \\
\hline 28 & $517-12$ & ICU & blood & $\mathrm{R}$ & $\mathrm{R}$ & $\mathrm{R}$ & - & $\mathrm{R}$ & $\mathrm{R}$ & $\mathrm{R}$ & $\mathrm{R}$ & $\mathrm{R}$ & - \\
\hline 29 & $520-12$ & ARC & resp. s-m & $\mathrm{S}$ & $\mathrm{S}$ & $\mathrm{S}$ & - & $\mathrm{S}$ & $\mathrm{R}$ & $\mathrm{I}$ & $\mathrm{R}$ & $\mathrm{R}$ & - \\
\hline 30 & $525-12$ & ARC & urine & $\mathrm{R}$ & $\mathrm{R}$ & $\mathrm{R}$ & - & $\mathrm{R}$ & $\mathrm{R}$ & $\mathrm{R}$ & $\mathrm{R}$ & $\mathrm{R}$ & - \\
\hline
\end{tabular}

ARC - Anestesiology and Resuscitation Clinic; ICU - Intensive Care Unit; HPS - Hepato - pancreatic surgery;

Traum. - Traumatology; Amb. - Ambulatory

Tzp - Piperacillin/Tazobactam; caz - Ceftazidime; fep - Cefepime; scf - Cefoperazon/Sulbactam; mem meropenem; amk - Amikacin; gen - Gentamycin; tbm - Tobramycin; cip - Ciprofloxacin; lvf - Levofloxacin.

\section{DNA Extraction}

The DNA of all isolates of $P$. aeruginosa was extracted using commercial kit E.Z.N.A. Bacterial DNA kit (10) according to the manufacturer's instructions and were used as template for PCR reactions.

\section{Multiplex PCR}

Multiplex PCR reaction was set up using specific primers for genes for fluoroquuinolone resistance (gyrA, parC) in P. aeruginosa and regulatory gene (mexR). For amplification of target genes was used Mastermix 2,0X VWR Red Taq DNA Polymerase with final concentration of $\mathrm{MgCl}_{2}-1,5 \mathrm{mM}$ (VWR GmbH International), specific primers from published data (7), synthesized by Integrated DNA Technology (Coralville, IA). PCR amplification was performed in $50 \mu$ f final volume: $25 \mu \mathrm{l}$ Master Mix, 10 pmol final concentration of each primer and $1 \mu \mathrm{l}(100 \eta \mathrm{g} / \mu \mathrm{l})$ of DNA template. Amplification of the target regions was performed in $35 \mathrm{PCR}$ cycles using following program: $95^{\circ} \mathrm{C}$ for $15 \mathrm{~min}, 95^{\circ} \mathrm{C}$ for $45 \mathrm{~s} 54^{\circ} \mathrm{C}$ for $45 \mathrm{~s}, 71^{\circ} \mathrm{C}$ for $1 \mathrm{~min}$ and $71^{\circ} \mathrm{C}$ for 7 minutes. $5 \mu 1$ of PCR products was analyzed by electrophoresis on $1 \%(\mathrm{wt} / \mathrm{vol})$ gel, stained with GelRed (Biotium, USA) and visualized under 
UV light. PCR product obtained from this step was used for Sanger sequencing.

\section{Sanger sequencing reaction}

Primers and free nucleotides from multiplex PCR reaction were removed using E.Z.N.A. ${ }^{\circledR}$ Cycle Pure kit (Q-spin) (Omega Bio-tek, USA) according to the manufacturer's instructions (Omega Bio-tek) The purified PCR products were directly sequenced by dideoxynucleotides using capillary electrophoresis system GeXP Genetic analysis system (Beckman Coulter, USA). Cycle sequencing reaction was performed using GenomeLab ${ }^{\text {TM }}$ DTCS Quick Start Kit (Beckman Coulter, USA) according to the manufacturer's instructions (11). This reaction was set up at $20 \mu \mathrm{l}$ final volume. Amplification of the target regions was performed in 30 cycles as follow: $96^{\circ} \mathrm{C}$ for $20 \mathrm{sec}, 50^{\circ} \mathrm{C}$ for $20 \mathrm{sec}$ and at $60^{\circ} \mathrm{C}$ for $4 \mathrm{~min}$. The PCR products were purified using ethanol precipitation and were resuspended in SLS buffer (Beckman Coulter, USA) and loaded on GeXP Genetic analysis system (Beckman Coulter, USA). All sequenced results were analyzed using Genome Lab GeXP software v.10.2. The sequences of the quinoloneresistance determining regions of gyrA and parC and the amplified region of mexR were compared with those from the corresponding quinolone- susceptible strain (PAO1) and the sequences present in the GenBank databases. GenBank accession numbers for the nucleotide sequences of gyrA, parC and mexR genes are L29417, D89652, U23763, and X65646, respectively.

\section{RESULTS AND DISCUSSION}

Multidrug-resistant (MDR bacterial infections are usually associated with big hospital complexes, like MMA in Sofia. It is a community hospital with 800 beds. The hospital is a one of the national centers for trauma, respiratory diseases, liver transplantation, patients' treatment, etc, with several surgery units and two ICUs / ICU and Anesthesiology and Resuscitation clinic (ARC). Antibiotic stewardship includes all groups of antibiotics together with carbapenems, quionolones, third and fourth generations of cephalosporins.

Thirty MDR P. aeruginosa strains (24 are resistant to ciprofloxacin with $\mathrm{MIC} \geq 4 \mathrm{mg} / \mathrm{l}$ ), isolated from different specimens at MMA, were investigated for the occurrence of mutations related to their resistance to quinolones.
Fragments of gyrA, parC and mex $\mathrm{R}$ genes were amplified using multiplex PCR and the efficacy of the amplification was estimated by gel electrophoresis. All fragments amplified adequately (Figure 1). The PCR products were after examined for detection of point mutations in the quinolone resistance-determining regions of gyrA and parC as well as for the efflux pomp regulatory mex $\mathrm{R}$ genes by the Sanger sequencing method on GeXP Genetic Analysis System (Beckman Coulter, USA). Mutations in all 24 fluoroquinolone-resistant strains occurred in codon 83 (Thr to Ile) and no mutation accured in codon 87 of the gyrA gene (Figure 2). Mutations in codons 87 (in 13 quinolone resistant strains) and 136 (in 3 quinolone resistant strains) were found in $\operatorname{parC}$ (Figure 3). A mutation related to fluoroquinolone resistance in codon 126 of the mexR regulatory gene, changing amino acid Val to Glu, was detected (Figure 4) and mutation in one strain in codon 44, changing amino acid Lys to Met was registered (Table 2). Non sence mutations in gyrA: codon 68 (Arg) - in 12 strains; codon 103 (Val) - in 7 strains; codon 118 (Ala) - in 7 strains; codon 132 (His) - in 13 strains; codon 136 (Ala) - in 7 strains have been observed. As a reference sequence were used sequences of genes gyrA, parC and MexR from P.aeruginosa PAO1. Alignment of sequences was performed using Genome Lab GeXP software v.10.2. (Figures 2, 3, 4)

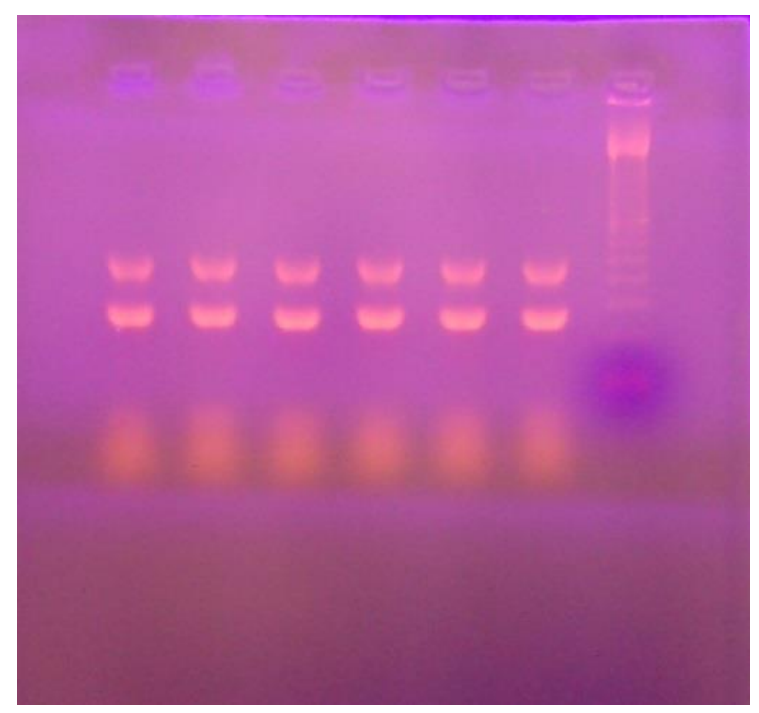

Figure 1. Electrophoresis analysis of PCR amplification of GyrA, ParC and MexR genes. / Due to the small difference in the length of the gyrA and parC fragments, they are observed as one wider and lighter band on the gel/ 
SAVOVE., et al.

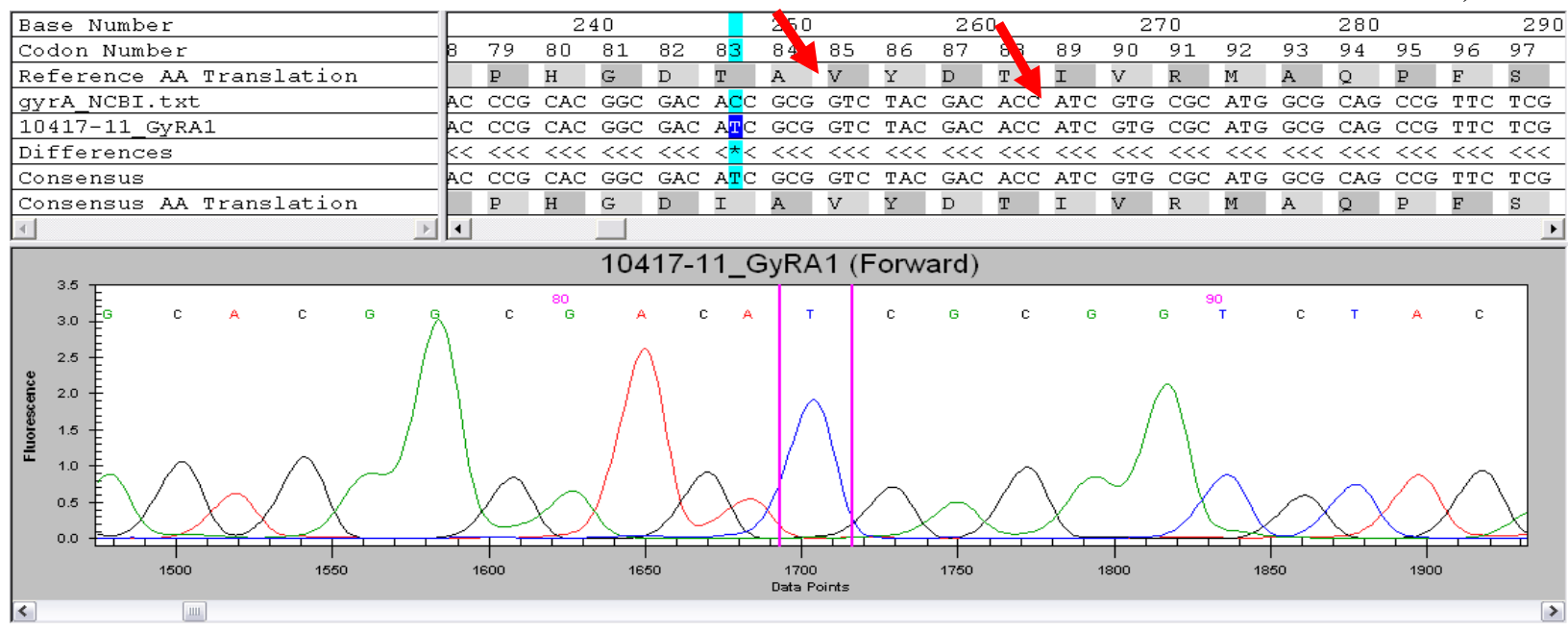

Figure 2. Alignment results of reference gene gyrA from PAO1 and one of investigated strains of P. aeruginosa

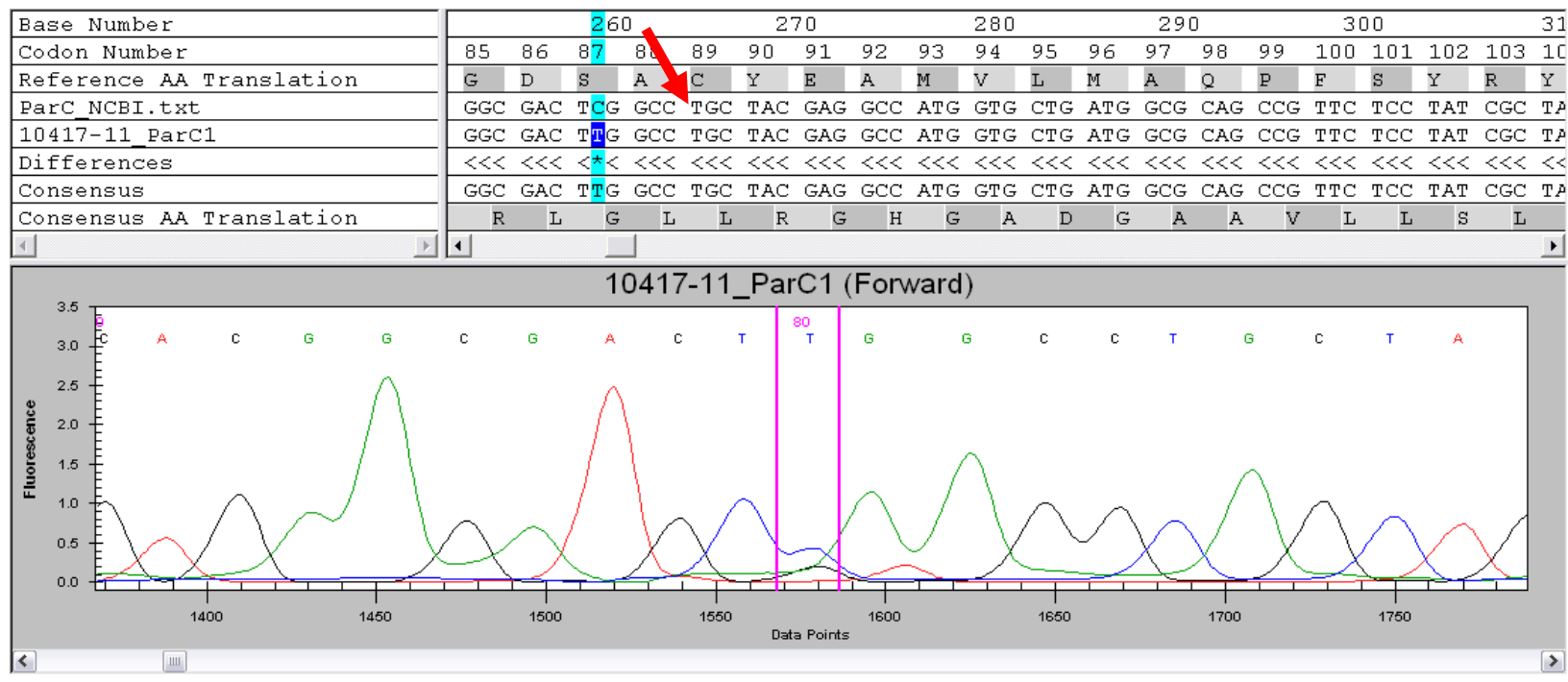

Figure 3. Alignment results of reference gene parC from $\mathrm{PAO} 1$ and one of investigated strains of $\mathrm{P}$. Aeruginosa

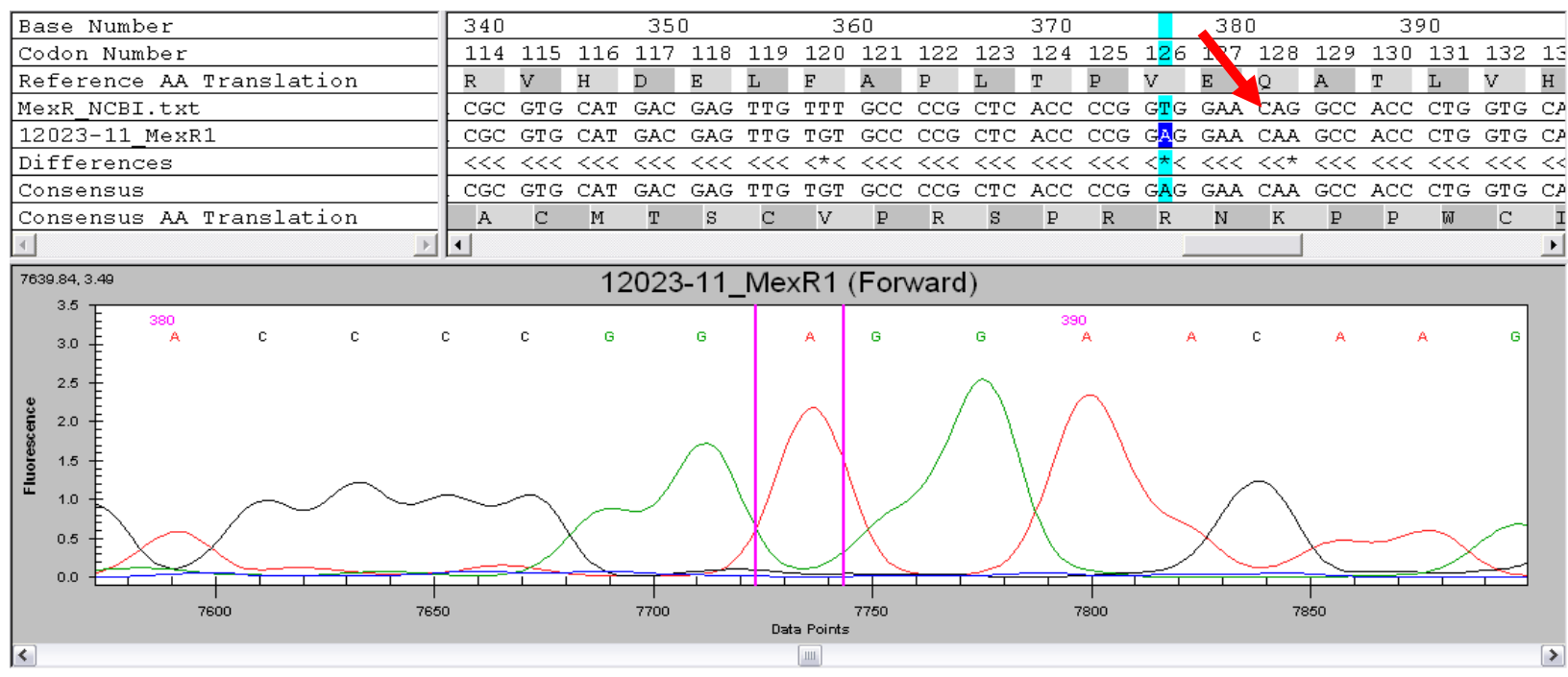

Figure 4. Alignment results of reference gene Mex R from PAO1 and one of investigated strains of P. aeruginosa 
Table 2. Point mutations in gyrA (codons 83), parC (87 and 136 codons) and mexR (44 and 126 codons) genes

\begin{tabular}{|c|c|c|c|c|c|c|c|}
\hline № & Lab № & Clinic & GyrA & \multicolumn{2}{|c|}{ ParC } & \multicolumn{2}{|c|}{ Mex R } \\
\hline \multicolumn{3}{|c|}{ № of codons } & 83 & 87 & 136 & 44 & 126 \\
\hline 1 & $9459-10$ & Traum. & no & no & no & no & yes \\
\hline 2 & $6489-11$ & Amb. & no & no & no & no & yes \\
\hline 3 & $9355-11$ & HPS & no & no & no & no & no \\
\hline 4 & $9802-11$ & ARC & yes & yes & no & no & no \\
\hline 5 & $10019-11$ & $\mathrm{ICU}$ & no & no & yes & no & no \\
\hline 6 & $10387-11$ & $\mathrm{ICU}$ & no & no & no & no & no \\
\hline 7 & $10417-11$ & ARC & yes & yes & no & no & no \\
\hline 8 & $10653-11$ & ARC & yes & yes & no & yes & yes \\
\hline 9 & $10944-11$ & ICU & yes & yes & no & no & yes \\
\hline 10 & $10950-11$ & ICU & yes & yes & no & no & yes \\
\hline 11 & 10983-11 & ARC & yes & yes & no & no & no \\
\hline 12 & 10993-11 & ARC & yes & no & no & \multicolumn{2}{|c|}{ No mex R } \\
\hline 13 & $11000-11$ & ARC & yes & yes & no & no & no \\
\hline 14 & 11974-11 & ARC & yes & yes & yes & no & no \\
\hline 15 & 12023-11 & ICU & yes & no & no & no & yes \\
\hline 16 & 12071-11 & ARC & yes & yes & no & no & no \\
\hline 17 & $12215-11$ & ARC & yes & yes & no & no & no \\
\hline 18 & $12245-11$ & ARC & yes & yes & no & no & yes \\
\hline 19 & $12275-11$ & ARC & yes & yes & no & no & no \\
\hline 20 & $12332-11$ & ARC & yes & yes & yes & no & no \\
\hline 21 & $12380-11$ & $\mathrm{ICU}$ & yes & yes & no & no & yes \\
\hline 22 & $12415-11$ & ICU & yes & no & no & no & yes \\
\hline 23 & 12451-11 & ARC & yes & yes & no & no & no \\
\hline 24 & $204-12$ & ARC & yes & yes & no & no & yes \\
\hline 25 & 411-12 & ICU & yes & yes & no & no & yes \\
\hline 26 & $465-12$ & ARC & yes & yes & no & no & no \\
\hline 27 & $507-12$ & Amb. & no & no & no & no & no \\
\hline 28 & $517-12$ & ICU & yes & yes & no & no & yes \\
\hline 29 & $520-12$ & ARC & yes & yes & yes & no & yes \\
\hline 30 & $525-12$ & ARC & yes & yes & no & no & no \\
\hline
\end{tabular}

Pseudomonas aeruginosa is usually a healthcareassociated pathogen, particularly in the subset of critically ill patients in ICUs. The resistance of nosocomial P.aeruginosa strains is significantly higher to antimicrobial drugs, used in the practice and the quinolones, aminoglycosides, carbapenems and colistin are the main classes used in the treatment of $\mathrm{P}$. aeruginosa infections at present. Unfortunately, the colistin usage in Bulgaria is not allowed, that means the scope of the drugs used for the treatment of such of infections, is very limited. The resistance, observed in $\mathrm{P}$. aeruginosa strains to quinolones, is another big problem in recent years. In comparison with the data, presented from ECDC (1) for $22.3 \%$ resistance of 8434 isolates from 28 countries, the resistance of P.aeruginosa strains, isolated during 2011 at MMA to ciprofloxacin was $70.6 \%$ of 170 strains estimated /dups excluded/ by AES of VITEK 2 (3). Here we only 
document known mutations in our strains. Similar point mutations, especially in $g y r A$ codon 83, were recently also reported in Acinetobacter baumannii strains by Deccache, Y. et al. (12). The mutations we registered in par $\mathrm{C}$ (codons 87 and 136) are different from those obtained by other authors $(13,14)$. No mutations were found in par $\mathrm{C}$ in the study done by Gorgani, N. et al., 2009 (7). No data were found in the literature regarding to a mutation in codon 136 and more studies are needed to determine whether this mutation is related to the resistance. On this background (our data together with these, obtained by other investigators) it can be considered, that gyrA mutations are the major mechanism of resistance to fluoroquinolones for clinical strains of $P$. aeruginosa and that additional mutations in parC could lead to a higher level of quinolone resistance (13). A mutation, detected in the codon 126 of mexR regulatory gene (changing amino acid Val to Glu), probably lead to the hyper expression of the efflux pump $M e x A B$ $\operatorname{OprM}(14,15)$. It was assumed, that a mexR mutation alone may not change the susceptibility of the bacteria but causes resistance when it cooccurs with a mutation on the gyrA gene (7).

In conclusion, this is the first report from Bulgaria, which confirms the results regarding the mechanisms of resistance to quinolones in clinical $P$. aeruginosa strains. The major mechanism of resistance of this bacterium to fluoroquinolones is the modification in $g y r A$ gene supplemented by possible changes in parC and mexR regions. The results, obtained by us on MDR $P$. aeruginosa, show that the same mutations found in strains from other nationalities are associated with the fluoroquinolone resistance. This suggests that the same mechanisms of fluoroquinolone resistance play an important role in MDR isolates from Bulgaria.

\section{REFERENCES}

1. ECDC surveillance report, 2010.

2. Jalal S, Ciofu O, Høiby N, Gotoh N, Wretlind B. Molecular mechanisms of fluoroquinolone resistance in Pseudomonas aeruginosa isolates from cystic fibrosis patients. Antimicrob Agents Chemother; 44:710-2, 2000.

3. MMA surveillance report, /For local use/, 2012.
4. Edalucci E, Spinelli R, Dolzani L, Lentizia Riccio , Dubois V, Angelo E, Tonin, Rossolini G, Lagatola C. Acquisition of different carbapenem resistance mechanisms by an epidemic clonal lineage of P. aruginosa. Clin Microbiol Infect.; 14:88-90, 2008

5. Nakano $M$, Deguchi $T$, Kawamura $T$, Yasuda M, Kimura M, Okano Y, et al. Mutations in the gyrA and parC genes in fluoroquinolone-resistant clinical isolates of Pseudomonas aeruginosa. Antimicrob Agents Chemother.; 41:2289-91q 1997.

6. Yonezawa M, Takahata M, Matsubara N, Watanabe Y, Narita H. DNA gyrase gyrA mutations in quinolone-resistant clinical isolates of Pseudomonas aeruginosa. Antimicrob Agents Chemother.;39:1970-2, 1995.

7. Gorgani N, Ahlbrand S, Patterson A, Pourmand N. Detection of point mutations associated with antibiotic resistance in Pseudomonas aeruginosa. Int J Antimicrobi Agents.; 34:414-8, 2009.

8. Bailey R, Scott E, Finegold S, Baron E. Diagnostic microbiology. Mosby Company, $7^{\text {th }}$ Ed. 1986.

9. Clinical and Laboratory Standards Institute, CLSI guideline, 2013.

10. Omega Bio-tek, USA, 2011.

11. GenomeLab ${ }^{\text {TM }}$ DTCS Quick Start Kit, Beckman Coulter, USA, Instructions, 608118AE, 2009.

12. Deccache R, Irenge L, Savov E, Aricius M, Macovei A, Trifonova A, Gergova I, Ambroise J, Vanhoof R, Gala JL. Development of pyrosequencing assay for rapid assessment of quinolone resistance in Acinetobacter baumannii isolates. $J$ Microbiol Methods.; 86:115-8, 2011.

13. Mouneimne H, Robert J, Jarlier V, Cambau E. Type II Topoisomerase mutations in Ciprofloxacin-resistant strains of Pseudomonas aeruginosa. Antimicrob Agents Chemother.; 43: 62-6, 1999

14. Salma R, Dabboussi F, Kassaa I, Khudari R, Hamze M. gyrA and parC Mutations in Quinolone-Resistant Clinical Isolates of Pseudomonas aeruginosa from Nini Hospital in North Lebanon. Int J Microbiol Res.; 3:82-6, 2012.

15. Livermore D. Multiple mechanisms of antimicrobial resistance in Pseudomonas aeruginosa: our worst nightmare? Clin Infect Dis.: 34: 634-40, 2022. 